\title{
ANALISIS DESAIN INTERIOR PERPUSTAKAAN DI DINAS PERPUSTAKAAN DAN KEARSIPAN KOTA PADANG PANJANG
}

\author{
Tania Yasmon ${ }^{1} \&$ Riya Fatmmawati ${ }^{2}$ \\ ${ }^{1}$ Mahasiswa Prodi Perpustakaan dan Ilmu Informasi Universitas Negeri Padang \\ 2 Dosesn Prodi Perpustakaan dan Ilmu Informasi Universitas Negeri Padang \\ email: taniayasmmon27@gmail.com
}

\begin{abstract}
This article aims to find out and describe how the interior design of the Padang Panjang City library includes a public reading room. A storage room (specifically for reference collections) and children's reading room. The data from this study were obtained from direct observations in the field by the author. Data analysis used descriptive qualitative data analysis which begins with collecting data, analyzing the data, then presenting the data obtained and then making inferences on the results obtained. From the results of data collection, it can be concluded that the interior design of the Padang Panjang City library has followed the applicable standards which based on color selection, furniture, ergonomics, and lighting provide comfort and friendliness to visitors.
\end{abstract}

Keywords : Interior Design, Library

\begin{abstract}
Abstrak
Artikel ini bertujuan untuk mengetahui serta mendeskripsikan bagaimana desain interior di perpustakaan Kota Padang Panjang yang meliputi ruang baca umum. Ruang tandon (khusus koleksi referensi) dan ruang baca anak. Data dari penelitian ini didapat dari hasil pengamatan langsung ke lapangan oleh penulis. Analisis data yang digunakah analisis data kualitatif deskriptif yang diawali dengan mengumpulkan data, menganalisis data, lalu menyajikan data yang didapat dan kemudian melakukan penyimpulan terhadap hasil yang didapat. Dari hasil pengumpulan data didapat kesimpulan bahwa desain interior perpustakaan Kota Padang Panjang sudah mengikuti standar yang berlaku dimana berdasarkan pemilihan warna, perabotan, ergonomi, dan pencahayaan memberikan kenyamanan dan ramah terhadap pengunjung.
\end{abstract}

Kata kunci: Desain interior, Perpustakaan 


\section{A. Pendahuluan}

Informasi dan ilmu pengetahuan semakin berkembang dan bertambah banyak dari waktu ke waktu sehingga membuat informasi yang tersebar menjadi tidak terkendali. Tidak terkendalinya informasi akan memicu berbagai permasalahan terutama permasalahan informasi palsu dikalangan masyarakat. Informasi palsu atau yang lebih sering disebut dengan Hoax terjadi akibat si penerima informasi tidak bisa menyaring informasi mana yang benar dan tidak, dia hanya menyebarkan informasi yang diadapat tanpa memerikasanya terlebih dahulu.

Fenomena di atas menjadi semakin buruk karena cepatnya informasi tersebar kepada masyarakat dengan bantuan teknologi informasi dan komunikasi yang semakin canggih dan serba cepat. Contoh penyebaran informasi yang paling cepat yaitu pada platform media sosial seperti instragram, facebook, dan aplikasi paling popular saat ini yaitu tiktok. Informasi yang telah tersebar kepada masyarakat dengan bantuan berbagai platform media sosial sulit untuk menanganinya sebab masyarakat terlanjur percaya pada informasi yang mereka lihat meskipun tidak tahu kebenarannya seperti apa.

Berdasarkan pemaparan di atas jelas bahwa informasi merupakan pusat dari segala pemikiran manusia. Informasi dapat merubah pola pikir manusia yang awalnya berpikiran positif bisa jadi negatif dan begitu sebaliknya. Untuk menjadikan masyarakat yang literat dibutuhkannya perpustakaan dimana salah satu fungsi perpustakaan yaitu memberikan informasi kepada pengguna tentunya informasi yang diberikan merupakan informasi yang telah disaring terlebih dahulu yaitu dari data kemudian diaolah menjadi sebuah informasi yang valid sehingga memberikan penerangan kepada pengguna yang awalnya memiliki keragu-raguan terhadap suatu informasi kemudian menjadi yakin terhadap suatu informasi.

Perpustakaan pada zaman sekarang bukan lagi sebuah gudang buku sebagaimana anggapan masyarakat dimasa lalu, melainkan sudah berkembang dan mengikuti perkembangan zaman. Citra perpustakaan sekarang lebih mengedepankan estetika dengan desain interior ruangan yang menarik sehingga pengunjung akan lebih nyaman serta ingin berlama-lama ke perpustakaan. Kehadiran perpustakaan di tengah masyarakat menjadi isyarat penting bahwa masyarakat tersebut bukan saja sebagai masyarakat literary (pandai baca tulis), tetapi juga masyarakat sense of knowledge (sadar pengetahuan). Perpustakaan tidak hanya berfungsi sebagai institusi yang mendorong masyarakat untuk gemar membaca dan menulis tetapi juga sekaligus sebagai penyedia fasilitas untuk sejumlah aktivitas ilmiah (Arianto, 2002).

Sasaran utama dari perpustakaan masa kini yaitu kalangan muda, dimana kalangan muda sekarang lebih suka pergi ke tempat-tempat hangout yang lebih aestetic dari segi tata ruangnya dari pada pergi ke perpustakaan. Untuk itu perpustakaan mendesain interior ruang perpustakaan semenarik dan senyaman mungkin untuk pengguna 
agar merasa betah dan sering berkunjung ke perpustakaan sehingga perpustakaan tidak lagi tempat belajar melainkan juga sebagai tempat mereka berkumpul dan berbagi informasi.

Desain interior atau tata ruang merupakan hal penting di suatu perpustakaan. Menurut Brown (1991), terdapat 10 dasar perencanan dan desain perpustakaan yang perlu diperhatikan, yaitu: 1. Fleksibel, 2. Lapang, 3. Akses mudah, 4. Dapat diperluas, 5. Bervariasi, 6. Terorganisir 7. Nyaman, 8. Lingkungan, 9. Aman, 10.Ekonomis (Sumadi, 2016). Perpustakaan melakukan berbagai cara untuk membuat tata ruang atau desain interior perpustakaannya dengan tujuan memberikan kesan estetika dan kenyamanan kepada pengunjung perpustakaan sehingga menarik minat pengunjung untuk pergi ke perpustakaan serta menyelamatkan bahan pustaka dari kerusakan. Desain interior dilakukan perpustakaan mulai dari pemilihan warna cat dinding perpustakaan tiap ruangnya hingga bagaimana tata letak rak buku. Dalam pembahasan berikut penulis akan membahas mengenai desain interior di perpustakaan terkhususnya perpustakaan kota Padang Panjang.

\section{B. Metodologi Penelitian}

Metode yang digunakan dalam pemecahan permasalahan termasuk metode analisis. Penelitian ini menggunakan pendekatan kualitatif deskriptif. Penelitian dilakukan di Dinas Perpustakaan dan Kearsipan Kota Padang Panjang. Tempat penelitian ini dipilih karena penulis melakukan insternship/kerja lapangan (magang) di perpustakaan tersebut sehingga lebih memudahkan penulis untuk mengumpulkan data.

\section{Hasil Penelitian dan Pembahasan}

\section{Desain interior ruang baca umum dan tandon}

Ruang perpustakaan penataannya harus sedemikian rupa sehingga ruang koleksi, ruang baca, ruang layanan, dan area kerja menjadi seimbang serta mengesankan perpustakaan yang nyaman dan bagus sesuai dengan sepuluh atribut ruang perpustakaan yang baik yaitu, fungsional, kemampuan beradaptasi, aksesibilitas, keragaman, interaktif, bermanfaat, ramah lingkungan, aman dan nyaman, efisien, dan sesuai untuk teknologi informasi (IFLA, 2020).

\section{Penempatan Rak Buku}

Untuk meletakkan rak buku dalam ruangan perpustakaan, pustakawan harus memperhatikan luas ruangan, banyaknya perabotan, penataan jendela, ketinggian 
pintu serta ketinggian langit-langit ruangan. Untuk hasil terbaik namun tempatnya terbatas, untuk itu posisi perabotan, pintu dan jendela harus diperhatikan. Posisi meja dan kursi untuk pengunjung yang digunakan untuk membaca diletakkan dibagian dinding terpendek, agar ruangan terlihat seimbang dan serasi. Pintu diletakkan di sudut ruangan agar penglihatan lebih jelas dan fokus pada ruangan.

Pada perpustakaan kota Padang Pajang, memiliki ruangan yang cukup luas sehingga untuk mengatur ruangan tidak begitu sulit. Meja dan kursi bagi pengunjung yang ingin membaca ditempat untuk ruang baca umum berada dibagian tengah-tengah dan diberikan jarak yang cukup antara dinging, meja dan kursi pengunjungan dengan rak buku sehingga ruang gerak pengunjung tidak dibatasi oleh dinding maupun rak buku. Rak buku yang berbentuk tabung diletakkan di sudut-sudut dinding perpustakaan untuk menghemat tempat dan terkesan seperti tiang bangunan perpustakaan. Untuk rak buku lainnya diletakkan di bagian dinding, di tengah pada bangunan perpustakaan. Perpustakaan kota Padang Panjang memiliki rak yang cukup tingga sehingga mereka menyediakan tangga untuk pemustaka agar tidak kesulitan dalam mengabil koleksi yang tinggi.

Pada ruang tandon atau khusus untuk koleksi referensi penempatan raknya sama dengan ruang baca umum, namun untuk meja dan kursi tidak disediakan karena yang diperbolehkan masuk ke ruang tandon hanya pustakawan dan pegawai saja. Ruang tandon juga sekaligus dijadikan ruang kerja bagi pustakawan dan pegawai.

\section{Tata Warna}

Pilihan warna mempengaruhi kondisi psikologis pengguna, memilih warna yang tepat akan membuat suasana hati yang baik dan kenyaman bagi pengguna pengguna serta pewarnaan dinding perpustakaan harus memberikan kesan nyaman untuk pengguna. Selain pewarnaan pada dinding, konsep pilihan warna yang tepat pada furniture perpustakaan juga harus diperhaatikan dengan baik (Kusrianto, 2007).

Tabel 1. Respon Psikologi Warna (Kusrianto, 2007) :

\begin{tabular}{|l|l|}
\hline \multicolumn{1}{|c|}{ Warna } & \multicolumn{1}{|c|}{ Respon psikologi yang mampu ditimbulkan } \\
\hline Merah & $\begin{array}{l}\text { Kekuatan bertenaga, kehangatan, nafsu, cinta, agresif, } \\
\text { bahaya }\end{array}$ \\
\hline Biru & Kepercayaan, konservatif keamanan, teknologi, \\
\hline
\end{tabular}


Literatify: Trends in Library Developments (Vol. 2 No. 1, 2021)

\begin{tabular}{|l|ll|}
\hline & kebersihan, pemerintahan & \\
\hline Hijau & $\begin{array}{l}\text { Alami, kesehatan, pandangan yang enak, } \\
\text { kecemburuan, pembaruan }\end{array}$ \\
\hline Kuning & $\begin{array}{l}\text { Optimis, harapan, filosof, ketidak jujuran, } \\
\text { kecurangan, pengecut, penghianatan }\end{array}$ \\
\hline Ungu & $\begin{array}{l}\text { Spiritual, misteri, keagungan, perubahan bentuk, } \\
\text { galak, arogan }\end{array}$ \\
\hline Orange & Energy, keseimbangan, kehormatan \\
\hline Coklat & Bumi, dapat dipercaya, nyaman, bertahan & \\
\hline Abu-abu & Intelek, futuristic, modis, kesenduan, merusak \\
\hline Putih & $\begin{array}{l}\text { Kemurnian/suci, bersih, kecermatan, tanpa dosa, } \\
\text { steril, kematian }\end{array}$ \\
\hline Hitam & $\begin{array}{l}\text { Kekuatan, seksualitas, kemewahan, kematian, misteri, } \\
\text { ketakutan, ketidak bahagian. }\end{array}$ \\
\hline
\end{tabular}

Pemilihan warna di perpustakaan Kota Padang Panjang sangat ramah di mata dan membuat nyaman. Warna yang dipilih yaitu warna cream dan warna coklat lembut. Warna ini terkesan elegan dan kalem sehingga terasa menenangkan dan membuat suasana hati yang baik. Untuk warna dinding, perpustakaan Kota Padang Panjang memilih warna cream dan untuk rak dipilih warna coklat lembut dan senada dengan warna dinding, warna karpet dipilih warna cream, untuk warna langit-langit dipilih warna putih agar menetralkan warna tone to tone dari dinding, rak dan karpet yang sudah ada, untuk warna lampu dipilih warna putih dimana cahayanya dibuat tidak terlalu terang dan tidak terlalu redup sehingga menghindari resiko silau pada lampu saat membaca.

\section{Pencahayaan}

Selain pemanfaatan interior dan ruangan yang baik, pencahayaan ruangan juga harus diperhatikan. Pencahayaan dapat berasal dari lampu (buatan) maupun sinar matahari (alami), pencahayaan tersebut harus mampu mencukupi intensitas cahaya yang dibutuhkan tidak lebih dan tidak kurang. Ini akan sangat membantu untuk mencari dan membaca koleksi yang ada diperpustakaan. Sistem yang perlu diperhatikan yaitu pencahayaan, karena kebutuhan utama perpustakaan adalah pengguna yang otomatis sebagai pembaca sehingga membutuhkan pencahayaan yang baik agar menimbulkan kenyamanan (Saputra \& Nurdiah, 2013).

Tabel 2. Standar pencahayaan untuk membaca (Grandjean, 1987) : 


\begin{tabular}{|l|l|c|}
\hline \multicolumn{1}{|c|}{$\begin{array}{c}\text { Jenis } \\
\text { Pekerjaan }\end{array}$} & \multicolumn{1}{|c|}{ Contoh } & $\begin{array}{c}\text { Penerangan yang } \\
\text { direkomendasikan } \\
\text { (lux })\end{array}$ \\
\hline Kasar & Ruang penyimpanan & $80-170$ \\
\hline $\begin{array}{l}\text { Kecermatan } \\
\text { sedang }\end{array}$ & $\begin{array}{l}\text { Pembungkusan dan } \\
\text { perakitan }\end{array}$ & $200-250$ \\
\hline $\begin{array}{l}\text { Kecermatan } \\
\text { tinggi }\end{array}$ & $\begin{array}{l}\text { Membaca, menulis, dan } \\
\text { laboran }\end{array}$ & $500-700$ \\
\hline $\begin{array}{l}\text { Kecermatan } \\
\text { sangat tinggi }\end{array}$ & $\begin{array}{l}\text { Arsitek, pewarnaan, } \\
\text { pengetesan, dan } \\
\text { meluruskan peralatan } \\
\text { elektronik }\end{array}$ \\
\hline
\end{tabular}

Pencahayaan yang digunakan di perpustakaan Kota Padang Panjang ada dua jenis yaitu pencahayaan buatan dengan bantuan lampu dan pencahayaan alami dengan bantuan sinar matahari. Pencahayaan menggunakan lampu downlight dipilih karena intensitas cahayanya cukup baik dan menyebar keseluruh ruangan. Pencahayaan alami dengan bantuan sinar matahari digunakan untuk penghematan sumber daya listrik sebab daya listrik yang dimiliki perpustakaan Kota Padang Panjang tidak terlalu besar, ketika menggunakan listrik yang berlebihan maka listrik akan otomatis mati dan akan mengganggu keberlangsungan kegiatan di perpustakaan. Perpustakaan meiliki cukup banyak jendela untuk membantu cahaya masuk dan membuat sirkulasi udara yang baik. Untuk keseluruhan ruangan, intensitas pencahayaan yang digunakan sama.

Perpustakaan kota Padang Panjang tidak memiliki AC karena memang notabene dari daerah Padang Panjang sendiri sudah dingin, jadi perpustakaan Kota Padang Panjang tidak melakukan pengaturan suhu dan kelembapan udara. Mereka hanya mengandalkan suhu ruangan alami dari jendela-jendela yang mereka miliki. Meskipun demikian, koleksi yang dimikili perpustakaan tidak ada yang mengalami kerusakan yang berarti dan ketika suhu yang terlalu dingin terjadi di daerah tersebut, tidak ada embun yang ada dibagian rak sehingga tidak merusak koleksi.

\section{Desain Interior Ruang Baca Anak}

\section{Penempatan Rak Buku}

Rak buku yang digunakan pada ruang baca anak berbentuk pergi panjang seperti rak buku pada umumnya. Rak yang ada di ruang baca anak ada dua jenis 
berdasarkan ketinggiannya yaitu rak buku yang pendek dimana itu akan terjangkau oleh anak-anak berumur 5 atau 6 tahun, lalu ada rak cukup tinggi jika disedikan tangga itu akan berbahaya bagi anak-anak, jadi yang ketika anak-anak meminta suatu koleksi maka pustakawan akan mengambilkannya jika.

Penempatan rak buku selalu berubah-ubah tergantung pada situasi sebab ruang baca anak tidak begitu luas. Ada banyak bantuan yang diberikan pemerintah untuk ruang baca anak terdapat berbagai macam permainan edukasi, perosotan dan kolam bola warna-warni sehingga ketika ada bantuan lagi berupa permainan edukasi maka rak buku akan dirombak lagi.

\section{Tata Warna}

Warna yang digunaka untuk dinding dan karpet pada ruang baca anak sama dengan warna yang digunakan untuk ruang-ruang lainnya. Akan tetapi untuk perabotan yang digunakan lebih berwarna. Warna-warna yang dipilih cenderung kewarnawarna pastel yang cerah jadi walaupun warnanya terkesan cerah tetapi nuannya yang ditonjolkan adalah nuansa ceria yang lembut karena dipilih pemilihan warna pastel.

\section{Pencahayaan}

Sama seperti pencahayaan yang digunakan untuk ruangan lainnya, pencahayaan pada ruang baca anak juga berasal dari pencahayaan buatan yaitu lampu dan pencahayaa alami yaitu sinar matahari yang disalurkan melalui jendela-jendela besar. Sirkulasi udara juga sangat baik karena jendela yang ada di ruang baca anak cukup banyak dan selalu dibuka agar udara di dalam menjadi sejuk.

\section{Daftar Pustaka}

Grandjean, E. (1987). Fiting the Task to the Man: An Ergonomic Approach. United Kingdom: Taylor\& Francis.

IFLA. (2020, November 15). Library Building and Equipment Section. Retrieved from Key Issues in Building Design: https://www.ifla.org/files/assets/library-buildingsandequipment/Publications/key-issues-in-b

Zuilding-design-en.pdf. 27/12/2018.

Kusrianto, A. (2007). Pengantar Desain Komunikasi Visual. Yogyakarta.

Saputra, D. A., \& Nurdiah, E. A. (2013). Perpustakaan Umum di Yogyakarta degan Pendalaman Sistem Pencahayaan. Jurnal Dimensi Arsitektur Petra, Vol. 1, No. 1, 1-5. 